\title{
YOUTUBE, CITRA MEDIA INFORMASI INTERAKTIF ATAU MEDIA PENYAMPAIAN ASPIRASI PRIBADI
}

\author{
Edy Chandra ${ }^{1}$ \\ ${ }^{1}$ Fakultas Seni Rupa dan Desain, Universitas Tarumanagara Jakarta \\ Email: edyc@fsrd.untar.ac.id
}

\begin{abstract}
ABSTRAK
Perkembangan internet berkembang dengan pesat sesuai dengan pertumbuhan perkembangan situasi sosial yang ada. Media sosial telah menjadi salah satu varian internet yang juga berkembang dengan pesat. Salah satu bentuknya adalah Situs Video YouTube. Walau dalam perkembangannya Situs Video YouTube tidak lagi hanya digunakan lagi sebagai media untuk mengunggah dan membagikan video-video pribadi kepada rekan-rekan terdekat saja, tetapi lebih dari itu. Dilihat dari pemikiran teori interculutural adaptation yang mengatakan bahwa saat ini Bangsa Indonesia telah masuk dalam tahap adaptation terhadap penggunaan berbagai media sosial termasuk Situs Video YouTube. Melalui para pengguna Situs Video YouTube yaitu seorang Presiden hingga para kaum millennial. Melalui pengumpulan informasi sumber-sumber yang ada dan mengolahnya kepada bentuk sebuah analisis konten materi Video, telah dihasilkan berbagai gambaran bagaimana Situs Video YouTube secara spesifik digunakan oleh para penggunanya sesuai dengan tujuan dan seleranya. Beberapa gambaran kemungkinan terhadap penggunaan Situs Video YouTube dapat dijelaskan lebih lanjut dan rinci.
\end{abstract}

Kata Kunci: komunikasi, video, blog, dan YouTube.

\section{PENDAHULUAN}

\section{Latar Belakang}

Pada era awal milenium internet merupakan media baru dalam kebutuhan akan penyediaan informasi bagi segelintir kelompok masyarakat di dunia. Dalam proses perkembangannya muncul fitur internet yang dikenal dengan istilah media sosial. Kaplan dan Haenlein (2010) memberikan definisi media sosial" sebuah kelompok aplikasi berbasis internet yang membangun di atas dasar ideologi dan teknologi web 2.0, dan yang memungkinkan penciptaan dan pertukaran user-generated content".

Kaplan dan Haenlein (2010) mengklasifikasikan media sosial menjadi enam jenis, yaitu: (a) Collaboration Project, yaitu sebuah situs yang memberikan izin otoritas kepada para penggunannya untuk mengubah, menambah, atau mengurangi konten-konten yang ada di dalam situs tersebut. Contohnya situs wikipedia. (b) Blog dan Microblog, yaitu situs yang berfungsi sebagai media dokumentasi berbagai catatan pribadi. Penggunanya secara pribadi dapat bebas meluapkan berbagai wacana pemikirannya dalam tulisan di situs tersebut. Contohnya : wordpress.com, kompasiana.com, dan lainnya. (c) Content Share, yaitu sebuah situs yang memberikan layanan berbagi konten dengan sesama pengguna dalam berbagai bentuk format video , gambar, hingga teks. Contohnya: vimeo.com dan slideshare.com. (d) Social Networks Site, yaitu situs atau aplikasi yang dapat mempertemukan antar pengguna dan saling terhubung satu dengan lainnya. Bentuk hubungan antar pengguna (berbagi) berupa fotofoto, teks, hingga informasi pribadi. Contohnya: friendster.com dan facebook.com. (e) Virtual Game World, yaitu situs lingkup dunia digital yang mereplika lingkungan (3 dimensi) dalam bentuk avatar. Para penggunanya dapat saling berinteraksi layaknya kehidupan nyata. Contohnya: situs game minecraft. (f) Virtual Social World, yaitu situs lingkup dunia digital yang mereplika kehidupan nyata manusia. Para penggunanya dapat saling berinteraksi layaknya kehidupan nyata. Contohnya: situs game second life.com. 
Secara umum media sosial memiliki ciri-ciri umum, yaitu: (a) pesan yang disampaikan dan diterima tidak meliputi antar personal tetapi meliputi multi pengguna; (b) pesan yang di sampaikan tidak terkontrol dan bebas; (c) pesan yang di sampaikan diproses lebih cepat di bandingkan media lainnya; (d) penerima pesan yang menentukan waktu interaksi.

Perkembangan enam klasifikasi media sosial semakin meningkat. Memasuki pasca tahun 2010 perkembangan media sosial semakin berkembang sesuai dengan situasi sosial masyarakat dunia. Salah satu bagian media sosial yang menjadi perhatian khusus bagi pengguna dari segala umur adalah klasifikasi media sosial content, yaitu situs Video sharing YouTube. Berbagai kalangan umur tertarik untuk menggunakan situs video sharing YouTube, sesuai dengan tema masingmasing dekade umur. Lebih tepatnya istilahnya adalah Situs video YouTube, telah banyak mulai diketahui dan digunakan oleh masyarakat di kota-kota besar sejalan dengan perkembangan penggunaan ponsel berbasis android yang menggunakan Google sebagai basis registrasinya. Seiring pula dengan peningkatan jumlah pengguna Situs video YouTube di Indonesia. Kontenkonten video yang ada semakin berkembang variannya dan juga di tinjau dari sisi positif dan negatifnya.

\section{Sejarah YouTube}

Tahun 2005 merupakan titik awal dari lahirnya situs video upload YouTube.com yang didukung oleh 3 (tiga) karyawan perusahaan finance online PayPal di Amerika Serikat. Mereka adalah Chad Hurley, Steve Chen, And Jawed Karim. Nama YouTube sendiri terinspirasi dari nama sebuah kedai pizza dan restoran Jepang di San Mateo, California.

Setahun sejak kelahirannya, pada tahun 2006 YouTube.com telah menjadi situs yang bertumbuh dengan cepat. Dengan diunggahnya video baru sebanyak 65.000 dan mencapai 100.000 video hingga bulan Juli 2006 ke situs video YouTube. Rekor tersebut mampu menembus 5 situs terpopuler di situs Alexa.com, jauh mengalahkan situs MySpace.com. Pada bulan Juni 2006 Situs video YouTube memasuki bidang kerjasama pemasaran dan periklanan dengan NBC.

Awal memasuki pasar internasional, pada bulan Oktober 2006 saham Situs video YouTube telah di beli oleh Google dengan nilai USD 1,65 Juta. Pada saat inilah awal dari Situs video YouTube mulai berkembang dan mencapai masa-masa kemapanan di tingkat internasional. Pada awal masa kemapanan Situs video YouTube mendapat penghargaan melalui majalah PC world dan mendapat julukan sembilan dari sepuluh produk terbaik di tahun 2006.

Dalam perkembangan portofolionya Situs video YouTube telah bekerjasama dengan berbagai intansi swasta maupun pemerintahan, yaitu: (a) July-Agustus 2007 menyelenggarakan siaran bersama dengan CNN acara debat Presiden Amerika; (b) November 2008 menyelenggarakan acara TV episode dan films secara online dengan bekerjasama dengan intansi media swasta di Amerika seperti: Lions Gate, CBS, NBC, Fox, dan Disney; (c) Awal tahun 2009 Situs video YouTube melakukan registrasi domain situsnya (www.YouTube-nocookie.com) untuk koleksi videonya yang berada dalam wilayah hukum pemerintah Amerika. Dan pada bulan November meluncurkan siaran pertunjukan bagi para penonton di Inggris yang menampilkan 4000 pertunjukan yang berasal dari 60 pihak ketiga yang bekerjasama dengan YouTube. (d) Pada bulan Maret 2010, YouTube mulai menyiarkan konten tertentu secara gratis, termasuk 60 pertandingan kriket Indian Premier League. Menurut YouTube, ini merupakan siaran acara olahraga besar via Internet pertama di dunia yang bersifat gratis. 
Selanjutnya, pada tanggal 31 Maret 2010, YouTube meluncurkan desain situs baru dengan tujuan menyederhanakan antarmuka dan meningkatkan waktu yang dihabiskan pengguna di situs ini. Manajer Produk Google Shiva Rajaraman berkomentar: "Kami merasa perlu mundur sedikit dan membereskan segalanya." Pada bulan Mei 2010, YouTube dilaporkan melayani lebih dari dua miliar video per hari, jumlah yang dianggap "nyaris dua kali lipat penonton primetime di ketiga jaringan televisi terbesar Amerika Serikat". Pada Mei 2011, YouTube melaporkan di blog perusahaannya bahwa situs ini menerima lebih dari tiga miliar kunjungan per hari. Bulan Januari 2012, YouTube menyatakan bahwa jumlah tersebut naik menjadi empat miliar per hari. Bulan Oktober 2010, Hurley menyatakan akan mengundurkan diri dari jabatan CEO YouTube dan menjadi penasihat perusahaan. Salar Kamangar akan mengambil alih kendali perusahaan ini.

Pada bulan April 2011, James Zern, seorang teknisi perangkat lunak YouTube, mengungkapkan bahwa 30 persen video di YouTube mewakili 99 persen kunjungan ke situs ini.

Pada November 2011, jejaring sosial Google+ terintegrasi langsung dengan YouTube dan penjelajah web Chrome, sehingga video-video YouTube bisa ditonton di Google+. Bulan Desember 2011, YouTube meluncurkan antarmuka baru. Kanal video ditampilkan di kolom tengah halaman utama, sama seperti umpan berita situs-situs jejaring sosial. Pada saat yang sama, versi baru logo YouTube dipasang dengan bayangan merah yang lebih gelap. Inilah perubahan desain pertama mereka sejak Oktober 2006.

\section{METODE PENELITIAN}

Dalam proses penelitian terhadap dampak persepsi para pengguna Situs video YouTube di kalangan kaum milenial dan orang dewasa yang melakukan unggah video ke Youtube, peneliti mengumpulkan informasi data-data informasi yang dimaksud dari berbagai sumber (media cetak koran dan majalah serta materi-materi online). Contoh figur subyek penelitian adalah akun Situs video YouTube milik para publik figur, yaitu: (a) Kaesang Pangarep (@kaesang), adalah Anak bungsu dari Presidaen RI Joko Widodo yang gemar melakukan publikasi hasil liputan pribadinya berupa video blog ke situs video YouTube. Jumlah pengikut (follower)/yang mendaftarkan diri (subscriber) berjumlah 250.000 subscriber; (b) Joko Widodo (@jokowidodo), ,merupakan Presiden RI ke 7 yang memiliki figur dan tampilan berbeda dari presiden sebelumnya. Salah satu perbedaannya adalah beliau cenderung menyukai selera dari para kaum milenial, salah satunya adalah musik rock dan menjelajah dunia sosial media. Jumlah pengikut (follower)/yang mendaftarkan diri (subscriber) berjumlah 165.000 subscriber; (c) Anya Geraldine (@ anyageraldine), dikenal dengan nama asli Nur Amalina hayati (mantan juara 1 Gading Model Search 2016), merupakan salah-satu pengguna Instagram dan situs video YouTube yang pernah menjadi pembicaraan publik dengan tayangan vulgar video bloggernya. Jumlah pengikut (follower)/yang mendaftarkan diri (subscriber) berjumlah 64.000 subscriber. (d) Karin Novilda (@awkarin). Merupakan salah satu pengguna Instagram yang telah menjadi pembicaraan dan trensetter model pakaian para kaum milenial Indonesia saat ini. Selain Instagram Karin juga memiliki akun situs video YouTube yang tidak kalah besar jumlah pengikutnya (follower). Jumlah pengikut (follower)/yang mendaftarkan diri (subscriber) berjumlah 165.000 subscriber.

Pertimbangan pemilihan subyek penelitian adalah pada tingkat popularitas (jumlah subscriber) dan dampak dalam masyarakat. Selain itu obyek penelitian merupakan bentuk akses unggah video dalam bentuk catatan harian informasi.

video Blog atau lebih dikenal dengan Vlogging. Istilah dasar dari Vlog mengacu kepada dictionary of cambridge.org, "a Video blog: a record of yourthoughts, opinions, 
orexperiences that you film andpublish on the internet" bahwa yang dimaksud adalah sebuah bentuk perekaman ungkapan pemikiran, pendapat, atau pengalaman yang direkam menjadi sebuah film dan di publikasi secara online melalui internet.

Selanjutnya setelah proses pengumpulan data, peneliti melakukan analisis dampak situasional pasca unggah video. Dampak pasca situasional berupa peningkatan atau berkurangnya jumlah viewer (penonton) pada akun sang pengungah, perkembangan jumlah varian judul video yang serupa, dan dampak-dampak sosial lainnya. Pada akhirnya dilakukan sebuah pengumpulan kunci fakta-fakta yang ada dan meramu menjadi sebuah pernyataan kesimpulan.

\section{HASIL DAN PEMBAHASAN}

\section{Situs Video Youtube Dalam Berbagai Perspektif Teoritis}

Situs video YouTube sebagai salah satu bagian dari social networking dalam kategori media sosial dalam perkembangannya telah menghasilkan berbagai dampak nilai-nilai bagi para penggunanya. Nilai-nilai yang dimiliki oleh para penggunanya. Selain kemudahan dalam berhubungan satu dengan lainnya tanpa dipengaruhi jarak dan waktu. Progress dan kecepatannya dalam mencapai sebuah popularitas telah terwujud bagi para penggunanya.

"Social media provide a place where people across the world can stay in touch and feel closer and more connected regardless of the distance that separates them. New social media have been rapidly spreading across the globe and gaining popularity in today's society." (Sawyer, 2011).

Situs video YouTube dengan fungsinya yang dapat menciptakan hubungan interaksi dan komunikasi yang sangat dekat antar para penggunannya. Pada akhirnya akan tercipta sebuah situasi adaptasi antar budaya (Intercultural Adaptation) pada masyarakat atau komunitas pengguna yang pada akhirnya dapat menciptakan sebuah transisi satu budaya menjadi budaya yang baru. Secara teoritis diungkapkan oleh Sawyer (dalam Chen \& Strarosta, 2005) bahwa dalam terdapat 4 (empat) tahapan melalui proses adaptasi antar budaya, yaitu: (a) Tahapan masa bulan madu (honeymoon), para masyarakat atau komunitas pengguna merasa sangat gembira (euphoria) dengan situasi yang dirasakan saat itu terhadap budaya barunya; (b) Tahapan masa krisis (crisis), merupakan sebuah situasi tidak nyaman dan frustasi pada masyarakat atau komunitas pengguna yang di temukan dan dirasakan pada sisi lain dari budaya baru tersebut. Nilai-nilia budaya yang dirasakan tidak familiar; (c) Tahapan Penyesuaian (adjustment), merupakan sebuah situasi para masyarakat atau komunitas pengguna mulai mencoba untuk menyesuaikan diri dengan budaya barunya; (d) Tahapan bikulturalisme (biculturalism), merupakan tahapan akhir dimana para masyarakat atau komunitas pengguna mulai menyesuaikan diri dengan budaya barunya.

Situs video YouTube sebagai kategori dari media sosial secara mayoritas digunakan oleh para pengguna yang memiliki sifat extrovert dalam kehidupan sosialnya. Situs video YouTube oleh para pengguna extrovert digunakan sebagai media komunikasi meningkatkan frekuensi eksistensi dan hiburan bagi para pengguna lainnya dalam masyarakat media sosial. Seorang extrovert yang memiliki sifat keterbukaan yang besar umumnya ingin selalu menampilkan dominasinya dalam kehidupan sosial. Salah satunya melalui media sosial. Hal ini diungkapkan dalam kutipan salah-satu penelitian, yaitu:

" Extroverts might also use YouTube frequently for entertaiment and/or to increase their online visibility." (Hamid, 2015). 
Dominasi dari para pengguna extrovert pada Situs video YouTube dapat disampaikan dengan berbagai macam varian tema vlogging yang di unggah ke Situs video YouTube. Dari isu tema yang berkembang di masyarakat hingga hal-hal sosial secara pribadi di kalangan kaum milenial. Semua konten-konten vlogging tersebut bagi para pengguna extrovert dianggap perlu untuk diungkapkan kepada publik. Gambaran hal ini juga telah disimpulkan melalui penelitian Christopher Cayari dari University of Illinois USA, yaitu:

"To some, YouTube is seen as a website full of amateurs wasting their time posting poorly made Video, while other see YouTube as Their Chance at stardom, their most understanding teacher, or their meeting place with closest friend. YouTube does allow for all these thing to happen. "(Cayari, 2011).

Jika mengacu kepada perkembangan vlogging di Indonesia. Pada tahun 2009 merupakan awal dari berkembangnya vlogging di Indonesia. Beredarnya video "Curhat" Marshanda di media Situs video YouTube dan berbagai siaran infotaiment di televisi. video yang berisikan ungkapan rasa kecewa sang artis Marshanda telah diunggah oleh pihak ketiga. Selain itu di tahun 2010 muncul video lipsink lagu Sinta-Jojo dan juga Gamaliel-Audrey yang menjadi pembicaraan berbagai media infotaiment di masyarakat. Sinta, Jojo, Gamaliel, dan Audrey dengan sengaja mengunggah video-video buatan mereka ke Situs video YouTube.

Tak luput pula dari berbagai kalangan masyarakat yang mulai gemar mengunggah video-video mereka ke Situs video YouTube. Seorang aparat polisi pun turut serta menjadi bagian dalam melakukan vlogging dalam bentuk video lipsink. Seorang aparat polisi bernama Briptu Norman telah melakukan unggah video Situs video YouTube ketika sedang bertugas. Dalam waktu singkat menjadi pembicaraan berbagai media infotaiment di masyarakat.

\section{Menerobos Protokol Komunikasi}

Dalam perkembangannya semakin besar minat masyarakat terhadap vlogger. Dapat disimak melalui pemikiran (Sawyer, 2011) bahwa Situs video YouTube telah dampak kemudahan komunikasi untuk berhubungan satu dengan lainnya dan semakin cepatnya meraih kepopularitasannya. Sang vlogger memiliki peran ganda sebagai aktor, kameramen sekaligus sutradara dalam tayangan video yang dibuat. Dapat dibayangkan sebelumnya sebuah tayangan figur publik seorang pejabat negara tidak terlepas dari berbagai proses pengaturan situasi dan penampilan diri mereka oleh tim protokoler kepresidenan. Seorang publik figur telah diatur sedemikian rupa dari cara berpakaian hingga cara berkomunikasi. Seorang pejabat negara harus menempuh sebuah aturan protokol ketika ingin menyampaikan sebuah pesan komunikasi saat di liput oleh berbagai media yang nantinya akan di tonton oleh jutaan pemirsa TV.

Proses aturan protokoler pejabat presiden tidak selalu sepenuhnya dilakukan oleh Presiden ke VII Indonesia Bapak Joko Widodo yang merupakan salah satu pejabat negara yang sangat gemar dan fokus terhadap dampak penggunaan media sosial, yaitu Situs video YouTube. 


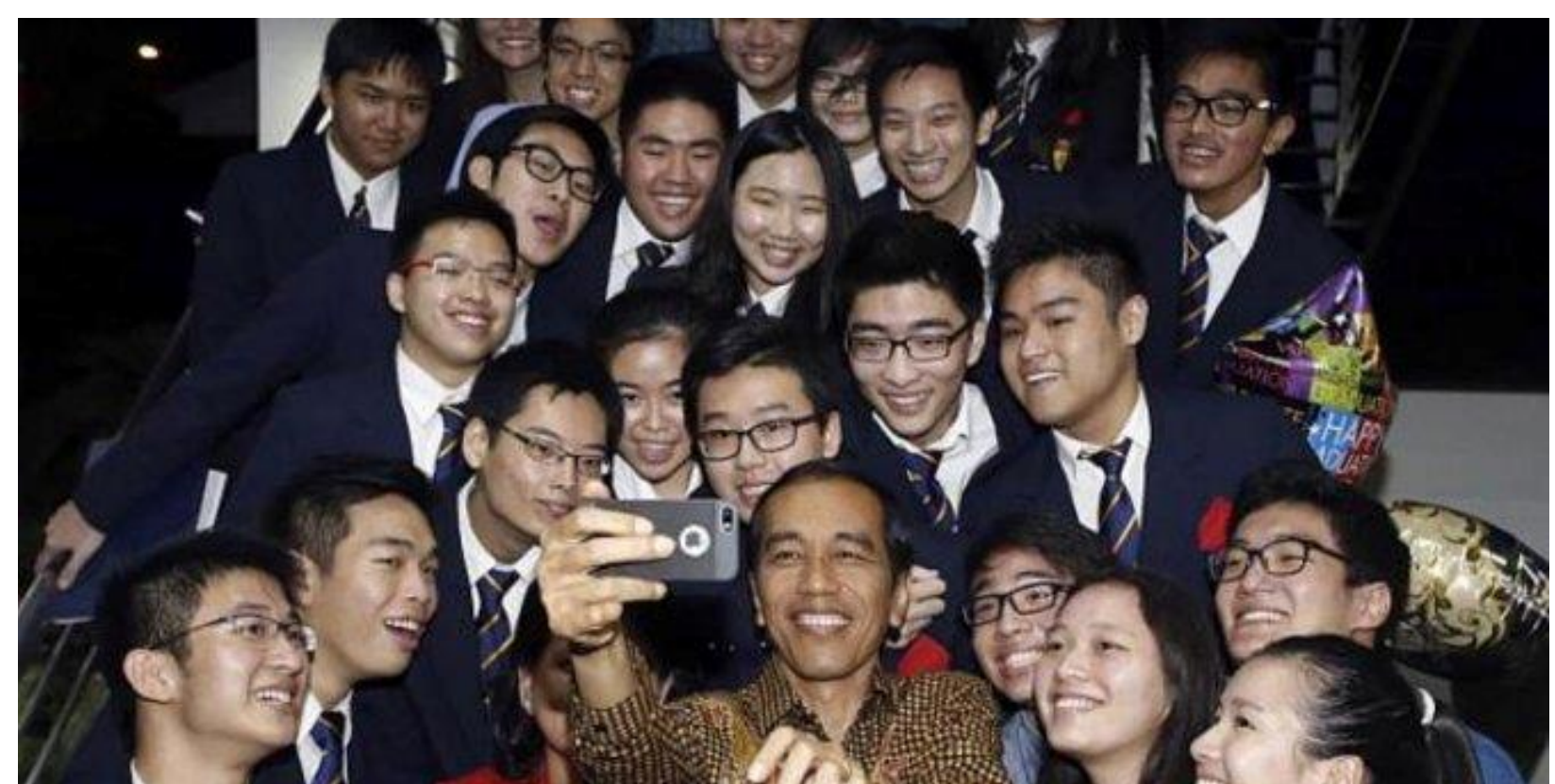

Gambar 1. Presiden Jokowi berwefie bersama dengan rekan wisudawan anaknya di Singapura. Sumber gambar: Majalah Straight Times

Presiden Jokowi seringkali melakukan unggah foto-foto hingga video hasil dokumentasi pribadinya ke berbagai media sosial termasuk ke situs video YouTube. Sebagai seorang Presiden sekaligus sebagai warga negara Indonesia yang saat ini sedang dilanda maraknya para pengguna Situs video YouTube sekaligus sebagai seorang vlogger. Tentunya beliau memiliki berbagai keinginan maupun ketertarikan terhadap berbagai hal selayaknya warga negara Indonesia biasa. Dalam akun Situs video YouTube Presiden Joko Widodo terdapat 2(dua) konten video yang dikategorikan vlog (video blogger), yaitu:

- "Vlog saya dari Piala Presiden 2017. Seru dan Meriah". Merupakan video blogger Presiden Jokowi ketika menghadiri kejuaran sepak bola Piala Presiden 2017. Dalam video tersebut yang telah di simak kurang lebih 403.182 viewer. Menggambarkan cerita bagaimana komentar dirinya yang tertarik kepada olahraga sepakbola dan juga hadir menjadi bagian dari penonton acara tersebut.

- “\#JKWVLOG Jamuan Makan Siang Bersama Raja Salman”. Merupakan video blogger Presiden Jokowi ketika sedang menyantap hidangan makan siang bersama Raja Salman saat kunjungan kenegaraan di Indonesia. Melalui 1.821.030 viewer Presiden Jokowi berusaha menyajikan bagaimana situasi dan respon Raja Salman terhadap Bangsa Indonesia melalui perspektif pribadinya kepada masyarakat lewat rekaman video pribadinya. Respon dan testimonial pribadi Raja Salman langsung melalui ponsel pribadi Presiden Jokowi.

Besarnya angka audiens (viewer) pada kedua video tersebut sebagai pengguna awal yang melakukan vlogging, mengambarkan bagaimana vlogger karya Presiden Jokowi Sangat di respon oleh para pengguna media sosial dari berbagai kalangan di Indonesia. Vlogger seorang presiden yang di tayangkan tanpa protokol presiden pada akhirnya menjadikan sembuah momen rekaman video yang menjadi bagian dari kebersamaan seorang presiden dengan masyarakatnya yang di mediasi oleh Situs video YouTube. 


\section{Vlogger Lebih Menarik di Bandingkan Blogger.}

"Menulis di blog menjadi hal yang membosankan bagi para kaum milenial saat ini." Kalimat inilah yang kita temukan pada salah satu koleksi video blogger (vlog) Kaesang dalam akun Situs video YouTube. Sebuah pernyataan, bahwa kemajuan teknologi pada akhirnya memberikan suasana can metode baru dalam mengekespresikan permasalahan-permasalahan sosial yang dihadapi saat ini melalui media komunikasi.

Dalam penelitian akademisi dari Malaysia, Norsiah Abdul Hamid telah menyimpulkan beberapa hal dalam penggunaan Situs video YouTube. Salah satunya telah dijadikan media komunikasi bagi para "extrovert" untuk tetap "eksis" dilingkungan sosialnya. Lalu, bagaimana dengan non "extrovert?" Salah-satunya adalah Kaesang Pangarep merupakan anak bungsu dari Presiden Jokowi yang memiliki akun di Situs video YouTube dan telah telah memiliki 250.000 subscriber. Dalam akun Kaesang terdapat banyak sekali koleksi video blogger karya Kaesang.

Diantara sekian banyak video blogger karya Kaesang. Terdapat 2(dua) video yang cukup menarik dan menjadi popular video di akun Kaesang, yaitu:

- "Pilok \#4 adu panco". Merupakan serial video blogger Kaesang yang ke IV. Secara sekilas cerita dalam video ini mengambarkan adegan adu panco antara anak dan ayahnya. Dalam adegan adu panco tersebut pada akhirnya dimenangkan oleh sang anak dan tanpa disangka pada akhir video sang ayah, yaitu Presiden Jokowi menyampaikan pesan moral kepada Kaesang serta kita semua bahwa "orang yang besar adalah orang yang kuat kesabarannya."

- "Pilok \#22 telepon neisha". Merupakan serial video blogger Kaesang yang ke XXII. Dalam video blogger ini Kaesang mencoba menceritakan. Bagaimana Presiden Jokowi mencoba memenuhi permintaan salah satu rakyatnya yang ingin menemuinya (seorang gadis cilik bernama Neisha). Pemenuhan sebuah permintaan dengan cara yang unik, yaitu menghubungi orang tua Neisha melalui telepon genggam putrinya (Kahiyang Ayu), lalu menghibur Neisha agar jangan menangis lagi setelah Presiden Jokowi meneleponnya. Situasi ini pada akhirnya di dokumentasikan dalam video blogger Kaesang.

Dalam koleksi-koleksi video blogger Kaesang telah menggambarkan bagaimana menciptakan sebuah vlogger jauh lebih mudah dibandingkan blogger (menulis catatan harian). Melalui akun Situs video YouTube jika mengikuti tahapan judul-judul vlogger yang dibuat oleh Kaesang terkait dengan judul "Pilok\# 1- 27". Maka akan ditemukan indikasi bahwa Kaesang merupakan seseorang yang memiliki sifat "Introvert". Dalam tahapan setiap video blogger yang di unggah akan terlihat perkembangan-perkembangan cara berkomunikasi yang meningkat dari seorang Kaesang. Berbagai video blogger yang diungkapkan oleh telah menggambarkan kesederhanaan seorang anak presiden dalam kehidupan sehari-harinya.

\section{Situs Video Youtube Telah Menjadi Menarik dan Menghibur}

Media komunikasi online merupakan sebuah media yang diciptakan agar manusia sebagai penggunanya dapat menjangkau lebih luas dan mudah dalam kehidupan sosialnya. Melalui pengembangan pada media sosial manusia diarahan untuk menciptakan sebuah komunitas secara virtual. Melalui media sosial manusia di edukasi untuk memperkenalkan profil diri mereka kepada masyarakat luas. Pada akhirnya manusia khususnya kaum milenial selanjutnya semakin 
tertarik terhadap kedua media tersebut. Porsi perhatian kepada media sosial semakin dianggap menantang bagi para penggunanya.

Anya Geraldine dan Karin Novilda merupakan dua orang video blogger yang telah menjadi perbincangan di masyarakat maupun dunia maya. Kedua gadis tersebut telah menjadi perbicangan kaitannya dengan gaya kehidupan sosial yang vulgar pada berbagai media sosial termasuk YouTube. Dalam kehidupan kesehariannya antara Anya Geraldine dan Karin Novilda yang lebih dikenal dengan nama Awkarin merupakan individu yang saling mengenal satu dengan lainnya keduanya memiliki pemahaman ideologi yang sama terhadap pandangan gaya hidup kaum milenial saat ini.

Salah satu vlogger yang diunggah dalam akun Karin Novilda yang menjadi contoh bahasan adalah:

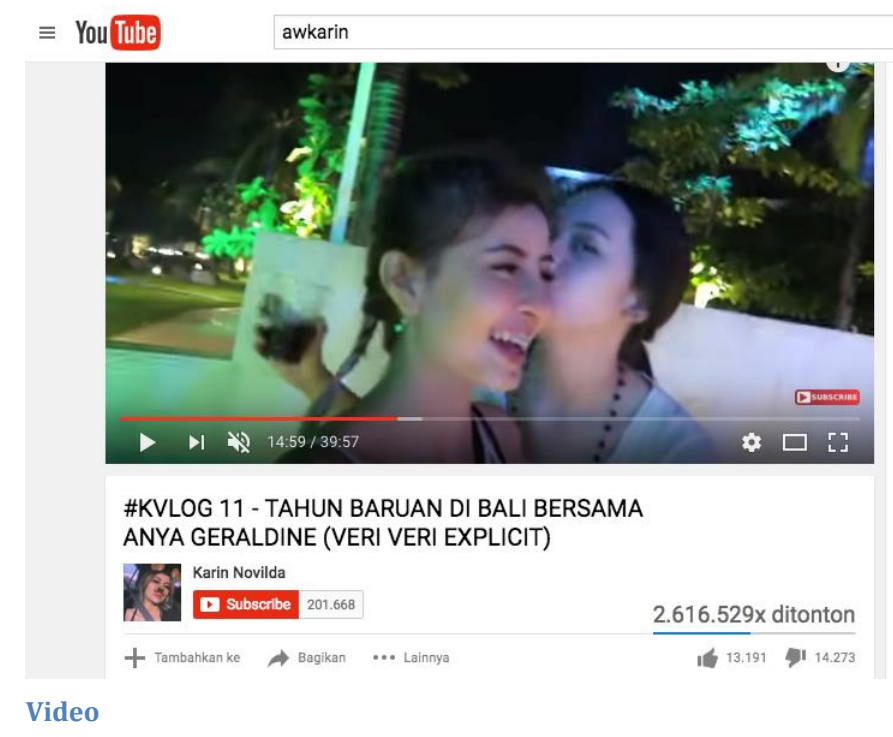

\section{Gambar 2. Unggahan Karin Novilda}

- \#KVLOG 11 - Tahun baruan Di Bali Bersama Anya Geraldine ('Veri Veri Explicit') merupakan sebuah video rekaman aktivitas Karin, Anya, beserta kekasih mereka ketika menjalani aktivitas liburan di Bali dan diunggah pada bulan Januari 2017 di situs video YouTube. Dalam rekaman video tersebut digambarkan bagaimana aktivitas kehidupan sosial Anya dan Karin sebagai kaum milenial yang ekspresif dengan kebebasan berperilaku. Dalam rekaman video tersebut tiada pertimbangan dalam berekspresi serta tidak peduli akan dampak pasca unggah video terhadap respon viewer $^{1}$ pada situs video YouTube.

Sejak perkembangan tren psycedelic di tahun 60an hingga saat ini. Persepsi kebebasan dalam hubungan di kehidupan sosial sudah menjadi tema utama dan semakin hari semakin meluas di artikan oleh masyarakat. Terutama di kalangan para kaum milenial. Meluasnya persepsi kebebasan dikalangan kaum milenial kian subur berkembang bersamaan dengan berkembangnya teknologi pada media sosial. Mengutip dari pandangan salah satu narasumber, yaitu:

\footnotetext{
1. Viewer merupakan istilah bagi para penonton/pemirsa di media sosial.
} 
...media sosial juga membuat segala sesuatunya menjadi menarik dan menghibur. Akibatnya, ia membuat kita tidak peduli dan tidak peka terhadap apa yang terjadi di sekeliling kita. Kita hanya cepat tanggap pada isu-isu yang sedang mengemuka di media sosial. Kita jadi kehilangan olah rasa tentang bagaimana menjadi seorang pribadi yang terinformasi secara komplit. (Iman; 2016)

Situs video YouTube sebagai bagian dari varian media sosial kian hari semakin memahami segala kebutuhan manusia sebagai mahluk sosial dalam pengembangan fitur-fiturnya. Para user/pengguna situs video YouTube di berikan tantangan untuk memberikan berbagai kontribusi konten-konten video pribadi mereka untuk di konsumsi secara meluas. Berbagi konten video menjadi visi dan misi bagi situs video YouTube telah mendorong keinginan yang menantang bagi para penggunanya.

...adanya ketercerabutan akibat ketidakmampuan kita dalam memilah antara identitas fisik dan identitas digital. Seorang pribadi dengan satu identitas fisik bisa memiliki beragam identitas digital. (Iman; 2016).

Poin-poin kebebasan dalam ideologi hubungan sosial sekaligus semakin tingginya rasa percaya diri akan penampilan fisik yang nyaris sempurna telah di buat oleh Anya Geraldine dan Karin Novilda dalam setiap rancangan foto maupun video yang mereka miliki. Telah menjadi sebuah contoh secara tidak langsung terhadap para kaum milenial lainnya sebagai alternatif situasi kehidupan sosial. Identitas digital yang tercipta oleh Anya dan Karin pada situs video YouTube pada akhirnya diciptakan untuk mendulang dukungan dari kalangan kaum milenial lainnya dalam mencapai persetujuan sebuah ideologi kebebasan yang lebih dalam hubungan sosial.

\section{Citra Media Informasi Interaktif atau Media Penyampaian Aspirasi Pribadi.}

Sesuai dengan konsep awalnya dibangunnya situs video YouTube sebagai salah-satu media sosial berbasis video yang di rancang untuk berbagi video dengan sesama rekan komunitas dan saling berkomentar satu dengan lainnya tentang hasil unggah video. Meningkatkan jumlah pengguna serta varian bentuk sajian video di YouTube. Telah membuka mata para penggunanya di seluruh dunia. Termasuk seorang Joko Widodo sebagai sang Presiden RI yang memiliki minat dan ketertarikan terhadap kemajuan era informasi online.

Presiden Joko Widodo termasuk juga Kaesang Pangarep sekaligus sebagai anak dari Presiden RI. Melihat Situs video YouTube merupakan media yang memiliki nilai potensial untuk menjalankan proses komunikasi massanya. Konsep komunikasi massa sendiri, yaitu:

...'Jenis komunikasi yang ditujukan kepada sejumlah khalayak yang tersebar heterogen, dan anonim melalui media cetak atau elektronis sehingga epsan yang sama dapat diterima secara serentak dan sesaat."(Jalaluddin, 2001).

Tentunya Sang Presiden RI Joko Widodo tidak mau kalah cepat dengan media massa nasional dalam memberitakan informasi-informasi kegiatan dirinya sebagai Presiden RI kepada masyarakat. Presiden Joko Widodo ingin tampil apa adanya dengan citra dirinya yang hanya ia dapat lakukan melalui penggunaan Situs video YouTube. Melalui cara ini beliau depat dengan bebas merancang profil dirinya sesuai dengan keinginan dirinya tanpa harus melalui proses protokoler kepresidenan. Tentunya apa yang dilakukan Presiden Joko Widodo tidak akan terwujud secara nyata bila dilakukan melalui proses penyiaran di media massa nasional, yang tentunya telah melewati proses-proses redaksional. 
Melalui Situs video YouTube, tentunya ungkapan-ungkapan komunikasi yang disampaikan oleh Presiden Joko Widodo tidak akan terpotong-potong oleh proses editing. Sebab sifat dari Situs video YouTube, pengguna adalah aktor sekaligus sutradara dari video yang dibuatnya.

Dari hasil unggahan koleksi videonya. Presiden Jokowi juga berharap bisa meraup berbagai komentar, saran, maupun kritik langsung dari rakyatnya melalui fasilitas komentar pada Situs video YouTube.

Layaknya sebuah kata kiasan "Like Father, Like Son." Apapun yang dilakukan oleh ayahnya begitu pula anaknya akan melakukan hal yang sama. Seorang Kaesang Pangarep yang merupakan anak bungsu dari Presiden Joko Widodo, juga menggunakan Situs video YouTube sebagai media untuk menuangkan segala komentar dan kritik terhadap masalah sosial yang ada termasuk juga komentar dan kritik kegiatan ayahnya sebagai Presiden RI. Seorang Kaesang berusaha berkomunikasi dengan seluruh masyarakat dunia virtual dan memposisikan dirinya pada sekmentasi kaum milenial. Melalui setiap karya vlog-nya telah menciptakan cukup banyak komentar-komentar positif dan tidak jarang juga komentar negatif, yang pada akhirnya menjadikan sebuah situasi komunikasi interaktif antara Kaesang dengan para pemirsa Situs video YouTube, sekaligus juga subscribernya ${ }^{2}$.

Hal situasional ini merupakan sebuah gambaran bawah penggunaan Situs video YouTube telah di gambarkan melalui pencitraan seorang Joko Widodo dan Kaesang Pangarep sekaligus sebagai bentuk gambaran bawah Situs video YouTube telah diposisikan sebagai media informasi yang bersifat interaktif.

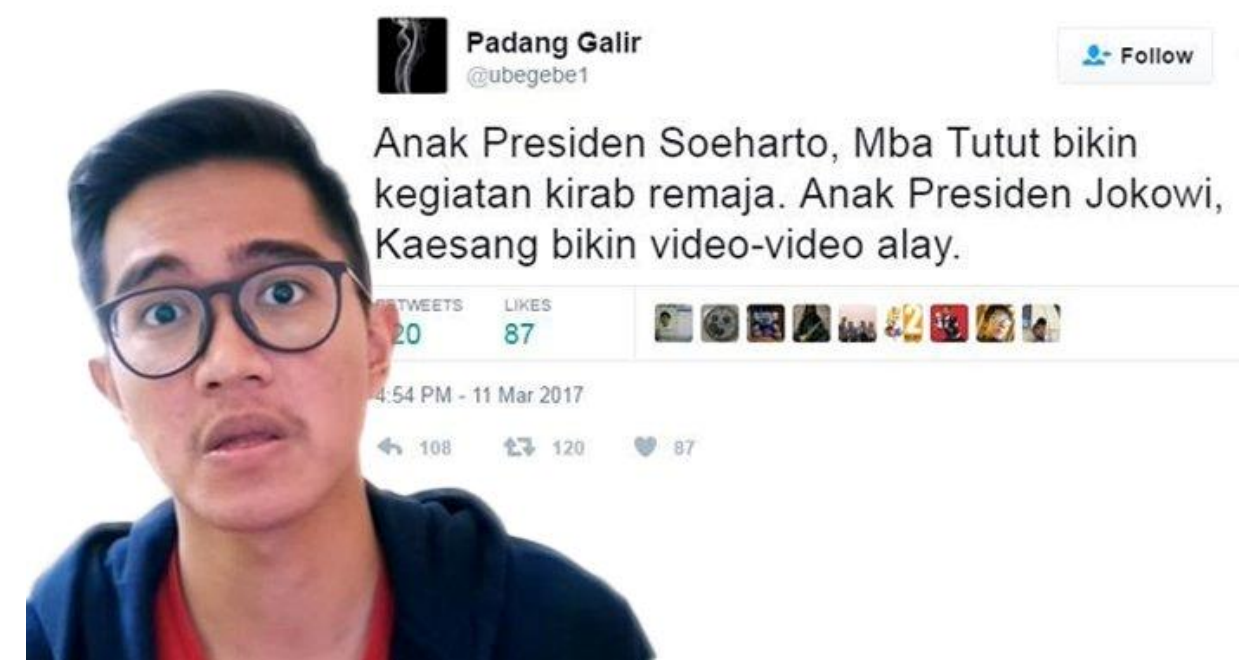

Gambar 2. Penggunaan YouTube oleh Kaesang Merupakan Bentuk Kekinian Gaya Komunikasi Seorang Anak Presiden RI

(Sumber :www.infomedia.net)

\footnotetext{
2. Subscriber merupakan para pemirsa Situs Video YouTube yang berlangganan pada channel/saluran tertentu di Situs
} Video YouTube. 
Pada lain hal terdapat pula anggapan bahwa Situs video YouTube merupakan sebuah media yang digunakan untuk menyampaikan aspirasi pribadinya. Telah kita ketahui dua dara muda, Anya Geraldine dan Karin Novilda yang merupakan sosok muda yang tengah beranjak melewati masamasa mudanya. Dengan memposisikan dirinya sebagai sosok kaum milenial bergaya urban metropolitan Anya dan Karin berusaha mengunggah karya-karya vlognya ke situs video YouTube. Melalui karya-karya vlog yang telah dihasilkan justru berisikan konten-konten laporan kegiatan keseharian dan perjalanan diri mereka dengan sekaligus menunjukan bagaimana situasi gaya hidup kaum milenial urban metropolitan yang menjunjung tinggi kehidupan bebas yang glamour. Tanpa mengkhawatirkan teguran dari orang tua mereka, bentuk-bentuk video ini terus menerus diproduksi dan dipertontonkan kepada seluruh masyarakat virtual di dunia.

Gambaran Anya dan Karin merupakan salah-satu figur yang mewakili penggunaan situs video YouTube sebagai media penyampaian informasi aspirasi pribadi yang tidak lagi mempedulikan nilai-nilai sosial yang ada di Indonesia.

\section{KESIMPULAN DAN SARAN}

\section{Kesimpulan}

Tidak sesederhana konsep yang diciptakan oleh Hurley, Chen, dan Karim terhadap situs video YouTube. Sebuah situs yang dibangun atas dasar keinginan hanya untuk berbagi video dengan rekan-rekan sekomunitas. Pada akhinya berkembang konsepnya mengikuti arus besar perkembangan teknologi dan informasi.

Tidak sebatas hanya membuat video dan berbagi kepada sesama rekan-rekan virtual saja, tetapi lebih dari itu. Situs video YouTube telah mendorong sebuah peminatan untuk menulis sebuah cerita kehidupan menjadi peminatan baru, yaitu peminatan untuk menceritakan kehidupan manusia dengan menggunakan media video dan bukan lagi menggunakan tulisan. Blogger bertransformasi menjadi Video Blogger.

Tidak hanya bertransformasi dalam metode-metode budaya kehidupan sosial yang ada, tetapi juga telah menghipnotis para penggunanya semakin asyik dan tenggelam dalam berbagai macam ide-ide khayalan yang terus berkembang pesat dalam menciptakan video-video yang ada.

Bahkan peran Situs video YouTube telah mempengaruhi seorang presiden untuk berperilaku di luar protokoler kepresidenan dalam menghasilkan video-video yang akan di unggahnya. Sisi positif maupun negatif bagaikan dua sisi mata uang yang tidak terpisahkan dari tujuan para pengguna Situs video YouTube, yaitu digunakan sebagai produksi media informasi interaktif atau media penyampaian aspirasi pribadi belaka.

\section{Saran}

Penelitian ini telah memberikan gambaran mengenai fenomena yang terjadi di dalam masyarakat. Peneliti menyarankan kajian lebih lanjut mengenai Situs video YouTube lainnya untuk memperoleh gambaran yang lebih lengkap mengenai konteks masyarakat masa kini, sehingga dapat tercapai pemahaman terhadap kondisi masyarakat secara lebih komprehensif.

Ucapan Terima Kasih (Aknowledgement)

Terima kasih kepada pihak- pihak yang terlibat dalam peneltian ini. Terima kasih juga kepada pihak Universitas Tarumanagara yang telah mendukung penelitian ini. 


\section{REFERENSI}

Kaplan, A M., Michael H. (2010). Users of the world, unite! The challenges and opportunities of social Media. Business Horizons, $x$, 56-88

Iman, N. (2016). Post-truth dan Medsos di Indonesia. Republika. Jakarta.

Sawyer, R. (2011). The impact of new social media on intercultural adaptation. Thesis of University of Rhone Island USA. Diunduh dari http://digitalcommons.uri.edu/srhonorsprog/242/.

Cayari, C. (2011). The Youtube effect: How YouTube has provided new ways to consume, Create, and Share Music. International Journal of Education \& The Arts, 12(6). Online : http://www.ijea.org/v12n6/.

Chandra, E. (2010). Budaya Populer dan Simulasi Realita Kaum millennial Jakarta Dalam Penggunaan Situs Video YouTube (Studi Kasus Unggah Video Gamaliel-Audrey dan Sinta-Jojo). Tesis. Universitas Mercubuana, Jakarta.

Chen, G.M., \& Strarosta, W.J. (2005). Foundations of Intercultural Communication. Lanham, MD: University Press of Amerika.

Dahl, S. (2015). Social Media Marketing. Theory \& Applications. Singapore, SG: Sage Publication

Hamid, M.A., Ishak, M.S., \& Yazam, S. (2015). Facebook, YouTube and Instagram: Exploring their effects on undergraduate students personality traits. Journal of SCIMPA University Utara Malaysia, 4(20), 138-165.

Lange, P.G (2008). Publicly private and privately public: Social networking on YouTube. Journal of Computer-Mediated Communication, 13(1), 361-380.

Rakhmat,J. (2001) Psikologi Komunikasi. Remaja Rosdakarya. Bandung 